\title{
Evaluation of Effect of Curcuma longa Supplementation on Production Parameters and Organ Weights in Induced Aflatoxicosis in Broiler Birds
}

\author{
L. Raja ${ }^{1 *}$, Chandan Kumar Singh ${ }^{3}$, M. Mondal ${ }^{2}$, S. Nety ${ }^{1}$ and K.M. Koley ${ }^{1}$ \\ ${ }^{1}$ Department of Veterinary Pharmacology and Toxicology, College of Veterinary Science and \\ A.H., CGKV, Durg, Chhattisgarh, India \\ ${ }^{2}$ Department of Teaching Veterinary Clinical Complex, Faculty of Veterinary and Animal \\ Sciences, West Bengal University of Animal and Fishery Sciences, Kolkata, India \\ ${ }^{3}$ Department of Veterinary Surgery and Radiology, College of Veterinary Science, Khanapara, \\ Assam Agricultural University, Assam, India \\ *Corresponding author
}

A B S T R A C T

The present study was undertaken to evaluate the ameliorative effects of Curcuma longa rhizome powder $(1 \%)$ in induced aflatoxicosis in broiler chicken. In this study, commercially available broiler chickens of Vencobb strain were reared from day one to

Keywords forty two days in the deep litter system of management and the birds were divided into three groups. Normal feed tested free of aflatoxin (AF), was given to the control (Group-

Aflatoxicosis, Curcuma longa, Broiler, Feed conversion ratio, Organ weight, Weight gain. 1). Aflatoxin (1 ppm) was supplemented with the feed to Group 2 and Curcuma longa $(1 \%)+\mathrm{AF}$ was supplemented with the feed to Group 3. Production parameters like body weight gain, Feed consumption, FCR, and relative organ weight were recorded. The results showed that the overall feed consumption, overall live weight of $C$. longa $+\mathrm{AF}$ treated birds(Group-3) at 6 weeks was significantly increased $(\mathrm{p}<0.01)$ as compared to birds treated with only AF (Group-2). The overall feed conversion ratio of AF alone (Group-2) Article Info

Accepted:

07 February 2017 Available Online: 10 October 2017 and $C$. longa $+\mathrm{AF}$ treated birds (Group-3) at 6 weeks were significantly increased $(\mathrm{p}<0.01)$ as compared to control, but no significant difference was observed in this respect between birds treated with $C$. long $a+\mathrm{AF}$ and birds treated with only AF. There was a significant rise in relative weights of liver, kidneys and spleen in the aflatoxinalone fed birds (Group-2) and the co-administration of C. longa (1\%) with the AF (Group-3) reduced the relative weights liver and kidney. In conclusion, the present study revealed that supplementation of Curcuma longa rhizome powder could partially ameliorate aflatoxicity in broilers.

\section{Introduction}

The poultry industry has seen tremendous growth in the recent past. Aflatoxicosis continues to be a major problem in many parts of the world, in spite of better understanding and sufficient advances. Studies on the mycotoxicosis gained momentum following the identification of aflatoxin (AF), a highly toxic and carcinogenic fungal metabolites produced by certain strains of fungus viz., Aspergillus flavus and Aspergillus parasiticus, as the causative factor of the turkey ' $\mathrm{x}$ ' disease (Blount, 1961; Abedi and Talebi, 2015). Of the aflatoxins, $B_{1}, B_{2}, G_{1}, G_{2}$ and $M_{1}$, the 
aflatoxin $B_{1}$ is the most potent toxin, affecting primarily the liver. At the sublethal, AF causes poor growth rate and immunosuppression in broilers. In India the problem of aflatoxicosis is more severe than in the developed countries due tropical and subtropical climatic conditions coupled to great economic losses to the poultry feed conversion. The frequent contamination and chronic exposure of this toxin to poultry causes a heavy economic loss to the farmers. To detoxify the AF, various methods have been tried such as removal of the toxin. However, practical and cost effective methods to detoxify/ degrade mycotoxin containing feed stuffs on a larger scale basis are not available. Now it is accepted that aflatoxin produce their deleterious effects and some of them are mediated via normal metabolite byproducts called free radicals (Yarru et al., 2009). These free radicals, if not bio transformed by antioxidant enzymes like GSH-Px, catalase, superoxide dismutase, cause injury to DNA, protein and lipid membrane. The convert and subtle damage brought by the free radicals could be effectively ameliorated by pepping up the antioxidant defence of the body and thus controlling aflatoxicosis.

Herbal drugs have been used traditionally in humans by physicians, herbalists and folk healers worldwide or for the prevention and treatment of liver diseases. Recent research is being focused on this aspect of utilizing plant substances as nutraceuticals in the prevention and treatment of diseases of metabolic and infectious origin both in veterinary and human medicine. Also phototherapy would serve as an alternative safe economical source of curbing loss in production especially in poultry. Bioflavonoids, a group of polyphenolic compounds, which are widely distributed in the plant kingdom, are claimed to have hepato-protective effect and hepato regenerative effects. Hence, the present experiment has been designed to study the genesis of oxidative stress in poultry due to fungal infections like aflatoxicosis and its alleviation by employing dried powdered rhizome of Curcuma longa (turmeric). $C$. longa has a wide spread of therapeutic effects including antitumor, anti-inflammatory, antibacterial, antiviral, antifungal and antispasmodic activities because of one of its major metabolites, tetrhydrocurcumin (Osawa, 2007). Curcumin inhibits the formation of covalent adducts between the aflatoxin and DNA by modulating cytochrome P 450 enzyme system (Firozi et al., 1996). Hence, addition of turmeric powder in poultry diet is envisaged to prevent the adverse effects of aflatoxicosis in poultry. Therefore, the present investigation has been undertaken to study the ameliorating effect of turmeric powder in induced aflatoxicosis in broiler birds on production performances parameters.

\section{Materials and Methods}

Production of aflatoxin: The AF was produced from Aspergillus flavus NRRL 18079 pure culture (Institute of Microbial Technology, Chandigarh, India) via fermentation of rice by the method of Shotwell et al., (1966). Fermented rice was then steamed to kill the fungus, dried and ground to fine crystalline powder. Hundred grams of powder from the culture substrate sample was sent to Animal Feed Analytical and Quality Control Laboratory, Veterinary College, Namakkal, Tamil Nadu, India for quantification of AF. The AF within the rice powder consisted of 165 ppm AFB1, 28 ppm AFB2 and $20 \mathrm{ppm}$ AFB2. The rice powder was added to the basal diet to provide the required amount of $1 \mathrm{ppm}\left(1 \mathrm{mg} \mathrm{kg}^{-1}\right)$.

\section{Collection and preparation of the plant material}

Curcuma longa rhizome was procured from the local market of Durg and identified from a 
botanist and was shade dried and reduced to fine powder using grinder and the powder was stored in airtight containers. The powder thus obtained was used in the present investigation.

\section{Chickens and diet}

The experimental investigation was planned for histopathological evaluation of protective potential of Curcuma longa on Aflatoxin induced toxicity in broilers after obtaining approval from Institutional Animal Ethics Committee. Clinically healthy ninety day-old, Cobb- 400 broiler chicks of both sexes, weighing 48- $50 \mathrm{~g}$ were obtained from a commercial hatchery and were reared on deep litter system of housing using rice husk with provision of artificial light at night.

The chicks were fed a standard commercial feed starter up to 14 days, thereafter a grower diet up to 28 days and finisher upto 42 days. Chickens were allowed access to the diets and fresh and clean drinking water ad libitum. The basal diets were tested for possible residual AF before feeding and there were no detectable levels present. All the experimental chicks were kept under close observation during entire period of study.

\section{Experiment design}

Chicks were weighed and randomly allotted into 3 groups of 30 chicks in each group having 3 replicates of 10 chicks in each group. Chicks of group-1 were kept as untreated control and were given only basal diet. Chicks of group -2 were given fed diet with aflatoxin @ 1 ppm from day first of experiment and considered as experimental aflatoxicosis group. Group-3 birds were fed diet with aflatoxin @ 1 ppm along with Curcuma longa powder @ 10 gm $/ \mathrm{kg}$ of feed as a treatment on mycotoxicosis from day first of experiment.

\section{Growth performance}

All birds were maintained fed for 42 days. Daily record of feed intake was done. Chicks were weighted weekly throughout the experiment. Weekly gain in body weight was calculated to determine the growth pattern and feed conversion ratio (FCR).

\section{Weekly live body weight}

Accurate body weight of individual experimental chick was recorded on electronic weighing balance at end of every week.

\section{Weekly gain in body weight}

Gain in body weight of chicks was calculated by subtracting the initial weight from the final weight at the end of every week.

\section{Weekly feed consumption}

A measured quantity of feed offered and quantity left over in 7 days was recorded. A weekly record of feed consumption was calculated in each treatment group by difference of feed offered and left over for every week.

\section{Feed conversion ratio (feed/gain)}

Feed conversion ratio of experimental chicks was calculated for every week from the recorded observations by using the following formula.

$$
\text { FCR }=\frac{\text { Quantity of feed consumed }(\mathrm{g})}{\text { Body weight gain }(\mathrm{g})}
$$

\section{Relative weight of organs}

Weights of lungs, liver, kidneys, heart, spleen, thymus and bursa of Fabricius were recorded 
after sacrificing the chicks by cervical dislocation on day 42 to calculate the relative organ weights as per following formula

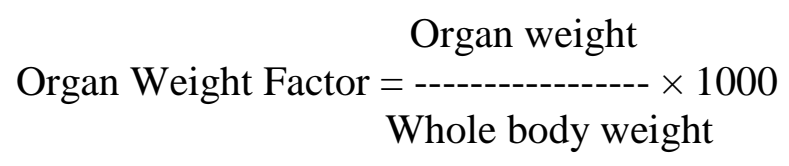

\section{Results and Discussion}

\section{The effects of supplementation of Curcuma} longa on performance parameters in induced aflatoxicosis in broiler birds.

\section{Effect on weekly live weight}

The effects of supplementation of $C$. longa on weekly live weightin induced aflatoxicosis in broiler birds are presented in Table 1 and Figure 1.

The live body weight (Mean \pm S.E) observed on 0 day, $1^{\text {st }}, 2^{\text {nd }}, 3^{\text {rd }}, 4^{\text {th }}, 5^{\text {th }}$ and $6^{\text {th }}$ week in the control group of birds were $46.8 \pm 0.34$, $137.63 \pm 2.19,315.45 \pm 4.29,620.35 \pm 5.79$, $1042.62 \pm 10.78,1403.49 \pm 14.70$ and $1712.86 \pm 17.37$ grams, respectively.

Live weight (Mean \pm S.E) observed on 0 day, $1^{\text {st }}, 2^{\text {nd }}, 3^{\text {rd }}, 4^{\text {th }}, 5^{\text {th }}$ and $6^{\text {th }}$ week in the only aflatoxin $(1 \mathrm{ppm})$ treated group of birds were $46.76 \pm 0.41,103.23 \pm 2.39,251 \pm 5.37,501$ $\pm 7.01,808.19 \pm 13.45,1124.2 \pm 19.95$ and $1380.4 \pm 19.80$ grams, respectively.

Live weight (Mean \pm S.E) observed on 0 day, $1^{\text {st }}, 2^{\text {nd }}, 3^{\text {rd }}, 4^{\text {th }}, 5^{\text {th }}$ and $6^{\text {th }}$ week in the aflatoxin $(1 \mathrm{ppm})+C$. longa $(1 \%)$ treated group of birds were $47.1 \pm 0.36,114.9 \pm 1.93$, $275 \pm 4.67,549.3 \pm 7.72,899.48 \pm 13.83$, $1217.3 \pm 18.88$ and $1483.26 \pm 22.52$ grams, respectively.

The results reported herein indicate that the supplementation of $1 \mathrm{ppm}$ aflatoxin alone in feed caused a significant decrease $(p<0.01)$ in mean live weight from $1^{\text {st }}$ week to $6^{\text {th }}$ week as compared to control. Supplementation of $C$. longa $(1 \%)+\mathrm{AF}(1 \mathrm{ppm})$ in feed also caused significant decrease $(p<0.01)$ in live body weight from $1^{\text {st }}$ week to $6^{\text {th }}$ week as compared to control but the live weight of the birds in $C$. longa $+\mathrm{AF}$ treated group was significantly higher $(\mathrm{p}<0.01)$ than the AF alone treated group.

\section{Effect on weekly body weight gain}

The effects of supplementation of $C$. longa on weekly body weight gainin induced aflatoxicosis in broiler birds are presented in Table 2 and Figure 2. The body weight gain (Mean \pm S.E) observed on $1^{\text {st }}, 2^{\text {nd }}, 3^{\text {rd }}, 4^{\text {th }}, 5^{\text {th }}$ and $6^{\text {th }}$ week in the control group of birds were $90.83 \pm 2.17,177.82 \pm 3.79,304.89 \pm$ $7.94,422.27 \pm 14.32,360.86 \pm 16.20,309.37$ \pm 22.98 grams, respectively.

Body weight gain(Mean \pm S.E) observed on 0 day, $1^{\text {st }}, 2^{\text {nd }}, 3^{\text {rd }}, 4^{\text {th }}, 5^{\text {th }}$ and $6^{\text {th }}$ week in the only aflatoxin $(1 \mathrm{ppm})$ treated group of birds were $56.46 \pm 2.38,147.37 \pm 4.29,252.81 \pm$ $8.28,306.42 \pm 14.45,315.44 \pm 20.70,256.2 \pm$ 27.66 grams, respectively.

Body weight gain(Mean \pm S.E) observed on 0 day, $1^{\text {st }}, 2^{\text {nd }}, 3^{\text {rd }}, 4^{\text {th }}, 5^{\text {th }}$ and $6^{\text {th }}$ week in the aflatoxin $(1 \mathrm{ppm})+C$. longa $(1 \%)$ treated group of birds were $67.8 \pm 1.97,0.89 \pm 4.97$, $274.85 \pm 9.36,350.18 \pm 17.11,317.81 \pm$ 23.08, 265.96 \pm 23.52 grams, respectively.

The results indicated that the supplementation of $1 \mathrm{ppm}$ aflatoxin alone and supplementation of $C$. longa $(1 \%)+$ the AF (1 ppm) in feed caused a significant decrease $(\mathrm{p}<0.01)$ in mean body weight gain from $1^{\text {st }}$ week to $4^{\text {th }}$ week as compared to control. However, the mean body weight gain of the birds in $C$. longa $+\mathrm{AF}$ treated group were significantly higher $(\mathrm{p}<0.01)$ than the AF alone treated group in $1^{\text {st }}, 2^{\text {nd }}$ and $4^{\text {th }}$ week. In $5^{\text {th }}$ and $6^{\text {th }}$ week, no significant differences were found among the different treatments. 


\section{Effect on weekly feed consumption}

The effect of supplementation of $C$. longa on weekly feed consumption in induced aflatoxicosis in broiler birds is presented in Table 3 and Figure 3. The feed consumption $\left(\right.$ Mean \pm S.E) observed on $1^{\text {st }}, 2^{\text {nd }}, 3^{\text {rd }}, 4^{\text {th }}, 5^{\text {th }}$ and $6^{\text {th }}$ week in the control group of birds $132.66 \pm 3.17,303.33 \pm 7.83,591 \pm 10.59$, $637.33 \pm 14.76,847.33 \pm 18.58$ and $947.33 \pm$ 24.56 grams, respectively.

Feed consumption (Mean \pm S.E) observed on $1^{\text {st }}, 2^{\text {nd }}, 3^{\text {rd }}, 4^{\text {th }}, 5^{\text {th }}$ and $6^{\text {th }}$ week in the only aflatoxin (1 ppm) treated group of birds were $111.33 \pm 2.60,284.33 \pm 5.92,503.33 \pm 11.86$, $553 \pm 7.21,749 \pm 20.80$ and $859.33 \pm$ 14.3grams, respectively.

Feed consumption (Mean \pm S.E) observed on $1^{\text {st }}, 2^{\text {nd }}, 3^{\text {rd }}, 4^{\text {th }}, 5^{\text {th }}$ and $6^{\text {th }}$ week in the aflatoxin $(1 \mathrm{ppm})+C$. longa $(1 \%)$ treated group of birds were $118 \pm 1.73,291.33 \pm$ $9.73,518.33 \pm 8.45,595 \pm 4.93,809.66 \pm$ 7.31 and $899.33 \pm 12.17$ grams, respectively.

From the above results, it was evident that the supplementation of $1 \mathrm{ppm}$ aflatoxin alone in feed caused a significant decrease in mean feed consumption from $1^{\text {st }}$ to $5^{\text {th }}$ week (except $2^{\text {nd }}$ week) as compared to control.

Supplementation of C. longa (1\%) + AF (1 $\mathrm{ppm})$ in feed also caused a significant decrease $(\mathrm{p}<0.01)$ in mean feed consumption on $1^{\text {st }}, 3^{\text {rd }}$ and $4^{\text {th }}$ week as compared to control but the feed consumption of the birds in $C$. longa $+\mathrm{AF}$ treated group were significantly higher than the AF alone treated group on $4^{\text {th }}$ and $5^{\text {th }}$ week. In $5^{\text {th }}$ week, there was no significant difference in feed consumption between the control group and the birds treated with $C$. long $a+\mathrm{AF}$. In $2^{\text {nd }}$ and $6^{\text {th }}$ week, no significant difference in feed consumption was noticed among the different treatments.

\section{Effect on weekly feed conversion ratio (FCR)}

The effects of supplementation of C. longa on weekly feed conversion ratio (FCR) in induced aflatoxicosis in broiler birds are presented in Table 4 and Figure 4 . The feed conversion ratio (Mean \pm S.E) observed on $1^{\text {st }}, 2^{\text {nd }}, 3^{\text {rd }}, 4^{\text {th }}, 5^{\text {th }}$ and $6^{\text {th }}$ week in the control group of birds were $1.46 \pm 0.12,1.70 \pm 0.06$, $1.94 \pm 0.01,1.51 \pm 0.04,2.34 \pm 0.10,3.07 \pm 0.12$, respectively.

FCR $\left(\right.$ Mean \pm S.E) observed on $1^{\text {st }}, 2^{\text {nd }}, 3^{\text {rd }}$, $4^{\text {th }}, 5^{\text {th }}$ and $6^{\text {th }}$ week in the only aflatoxin (1 ppm) treated group of birds were $1.97 \pm 0.11$, $1.92 \pm 0.06,2.00 \pm 0.19,1.80 \pm 0.07,2.39 \pm$ $0.19,3.40 \pm 0.30$, respectively.

FCR(Mean \pm S.E $)$ observed on $1^{\text {st }}, 2^{\text {nd }}, 3^{\text {rd }}, 4^{\text {th }}$, $5^{\text {th }}$ and $6^{\text {th }}$ week in the aflatoxin $(1 \mathrm{ppm})+C$. longa $(1 \%)$ treated group of birds were $1.74 \pm$ $0.09,1.81 \pm 0.07,1.88 \pm 0.05,1.70 \pm 0.08$, $2.55 \pm 0.09,3.38 \pm 0.14$, respectively.

From the above results, it is observed that the supplementation of $1 \mathrm{ppm}$ aflatoxin alone and supplementation of C. longa $(1 \%)+$ the AF (1 $\mathrm{ppm}$ ) in feed caused a significant increase in mean feed conversion ratio on $1^{\text {st }}$ and $4^{\text {th }}$ week as compared to control. In the remaining weeks $\left(2^{\text {nd }}, 3^{\text {rd }}, 5^{\text {th }}\right.$ and $\left.6^{\text {th }}\right)$ there was no significant difference among the different treatments.

\section{Effect on overall live weight}

The overall live weight of the birds of different groups was presented in Table 5 and Figure 5. The overall live weight at 6 weeks in the control, aflatoxin alone and C. longa (1 $\%)+$ AF treated groups of birds were 1712.81 $\pm 5.22,1381 \pm 11.53,1483.67 \pm 16.01$ grams, respectively. The overall live weight of both $\mathrm{AF}$ alone and $C$. longa $+\mathrm{AF}$ treated groups at 6 weeks were significantly lower $(p<0.01)$ as 
compared to control. However, the same was significantly higher $(\mathrm{p}<0.01)$ in $C$. longa $+\mathrm{AF}$ treated groups as compared to birds treated with only AF.

Table.1 Effects of supplementation of C. longa on weekly live weight ( $\mathrm{g}$ ) in induced aflatoxicosis in broiler birds

\begin{tabular}{|l|l|l|l|l|l|l|l|}
\hline Groups & 0 Day & $\begin{array}{l}\mathbf{1}^{\text {st }} \\
\text { Week }\end{array}$ & $\begin{array}{l}\mathbf{2}^{\text {nd }} \\
\text { Week }\end{array}$ & $\begin{array}{l}\mathbf{3}^{\text {rd }} \\
\text { Week }\end{array}$ & $\begin{array}{l}\mathbf{4}^{\text {th }} \\
\text { Week }\end{array}$ & $\begin{array}{l}\mathbf{5}^{\text {th }} \\
\text { Week }\end{array}$ & $\begin{array}{l}6^{\text {th }} \\
\text { Week }^{-1}\end{array}$ \\
\hline Control & 46.8 & 137.63 & 315.45 & 620.35 & 1042.62 & 1403.49 & 1712.86 \\
& \pm 0.34 & $\pm 2.19^{\mathrm{a}}$ & $\pm 4.29^{\mathrm{a}}$ & $\pm 5.79^{\mathrm{a}}$ & $\pm 10.78^{\mathrm{a}}$ & $\pm 14.70^{\mathrm{a}}$ & $\pm 17.37^{\mathrm{a}}$ \\
\hline Aflatoxin & 46.76 & 103.23 & 251 & 501 & 808.19 & 1124.2 & 1380.4 \\
& \pm 0.41 & $\pm 2.39^{\mathrm{c}}$ & $\pm 5.37^{\mathrm{c}}$ & $\pm 7.01^{\mathrm{c}}$ & $\pm 13.45^{\mathrm{c}}$ & $\pm 19.95^{\mathrm{c}}$ & $\pm 19.80^{\mathrm{c}}$ \\
\hline Turmeric + & 47.1 & 114.9 & 275 & 549.3 & 899.48 & 1217.3 & 1483.26 \\
Aflatoxin & \pm 0.36 & $\pm 1.93^{\mathrm{b}}$ & $\pm 4.67^{\mathrm{b}}$ & $\pm 7.72^{\mathrm{b}}$ & $\pm 13.83^{\mathrm{b}}$ & $\pm 18.88^{\mathrm{b}}$ & $\pm 22.52^{\mathrm{b}}$ \\
\hline
\end{tabular}

Values are mean \pm SE of 30 observations $(n=30)$

Mean with different superscript in column wise are differing significantly $(\mathrm{P}<0.01)$

Table.2 Effects of supplementation of $C$. longa on weekly body weight gain (g) in induced aflatoxicosis in broiler birds

\begin{tabular}{|c|c|c|c|c|c|c|}
\hline Groups & $\begin{array}{l}1^{\text {st }} \\
\text { Week }\end{array}$ & $\begin{array}{l}2^{\text {nd }} \\
\text { Week }\end{array}$ & $\begin{array}{l}3^{\text {rd }} \\
\text { Week }\end{array}$ & $\begin{array}{l}4^{\text {th }} \\
\text { Week }\end{array}$ & $\begin{array}{l}5^{\text {th }} \\
\text { Week }\end{array}$ & $\begin{array}{l}6^{\text {th }} \\
\text { Week }\end{array}$ \\
\hline Control & $\begin{array}{l}90.83 \\
\pm 2.17^{\text {a }}\end{array}$ & $\begin{array}{l}177.82 \\
\pm 3.79^{\mathrm{a}}\end{array}$ & $\begin{array}{l}304.89 \\
\pm 7.94^{\mathrm{a}}\end{array}$ & $\begin{array}{l}422.27 \\
\pm 14.32^{\text {a }}\end{array}$ & $\begin{array}{l}360.86 \\
\pm 16.20\end{array}$ & $\begin{array}{l}309.37 \\
\pm 22.98\end{array}$ \\
\hline Aflatoxin & $\begin{array}{l}56.46 \\
\pm 2.38^{c}\end{array}$ & $\begin{array}{l}147.37 \\
\pm 4.29^{\mathrm{c}}\end{array}$ & $\begin{array}{l}252.81 \\
\pm 8.28^{b} \\
\end{array}$ & $\begin{array}{l}306.42 \\
\pm 14.45^{c}\end{array}$ & $\begin{array}{r}315.44 \\
\pm 20.70 \\
\end{array}$ & $\begin{array}{l}256.2 \\
\pm 27.66 \\
\end{array}$ \\
\hline $\begin{array}{l}\text { Turmeric + } \\
\text { Aflatoxin }\end{array}$ & $\begin{array}{l}67.8 \\
\pm 1.97^{\mathrm{b}} \\
\end{array}$ & $\begin{array}{l}160.89 \\
\pm 4.97^{\mathrm{b}} \\
\end{array}$ & $\begin{array}{l}274.85 \\
\pm 9.36^{\mathrm{b}} \\
\end{array}$ & $\begin{array}{l}350.18 \\
\pm 17.11^{\mathrm{b}}\end{array}$ & $\begin{array}{l}317.81 \\
\pm 23.08 \\
\end{array}$ & $\begin{array}{r}265.96 \\
\pm 23.52 \\
\end{array}$ \\
\hline $\begin{array}{l}\text { Level of } \\
\text { Significance }\end{array}$ & $* *$ & $* *$ & $* *$ & $* *$ & NS & NS \\
\hline
\end{tabular}

Values are mean \pm SE of 30 observations $(n=30)$

Mean with different superscript in column wise are differing significantly

$* * \mathrm{P}<0.01, * \mathrm{P}<0.05$, NS- Non Significant

Table.3 Effects of supplementation of $C$. longaon weekly feed consumption (g) in induced aflatoxicosis in broiler birds

\begin{tabular}{|l|l|l|l|l|l|l|}
\hline Groups & $\mathbf{1}^{\text {st }}$ & $\mathbf{2}^{\text {nd }}$ & $\mathbf{3}^{\text {rd }}$ & $\mathbf{4}^{\text {th }}$ & $\mathbf{5}^{\text {th }}$ & $\mathbf{6}^{\text {th }}$ \\
& $\mathbf{W e e k}^{\text {Week }}$ & $\mathbf{W e e k}^{\text {Week }}$ & Week $^{\text {Week }}$ \\
\hline Control & 132.66 & 303.33 & 591 & 637.33 & 847.33 & 947.33 \\
& $\pm 3.17^{\text {a }}$ & \pm 7.83 & $\pm 10.59^{\text {a }}$ & $\pm 14.76^{\text {a }}$ & $\pm 18.58^{\text {a }}$ & $\pm 24.56^{\text {a }}$ \\
\hline Aflatoxin & 111.33 & 284.33 & 503.33 & 553 & 749 & 859.33 \\
& $\pm 2.60^{\mathrm{b}}$ & \pm 5.92 & $\pm 11.86^{\mathrm{b}}$ & $\pm 7.21^{\mathrm{c}}$ & $\pm 20.80^{\mathrm{b}}$ & $\pm 14.3^{\mathrm{ab}}$ \\
\hline Turmeric + & 118 & 291.33 & 518.33 & 595 & 809.66 & 899.33 \\
Aflatoxin & $\pm 1.73^{\mathrm{b}}$ & \pm 9.73 & $\pm 8.45^{\mathrm{b}}$ & $\pm 4.93^{\mathrm{b}}$ & $\pm 7.31^{\mathrm{a}}$ & $\pm 12.17^{\mathrm{a}}$ \\
\hline Level of & & & & & & \\
Significance & $* *$ & $\mathbf{N S}$ & $* *$ & $* *$ & $*$ & $*$ \\
\hline
\end{tabular}

Values are mean \pm SE of 30 observations $(n=30)$

Mean with different superscript in column wise are differing significantly

$* * \mathrm{P}<0.01, * \mathrm{P}<0.05$, NS- Non Significant 
Table.4 Effects of supplementation of $C$. longa on weekly feed conversion ratio in induced aflatoxicosis in broiler birds

\begin{tabular}{|l|l|l|l|l|l|l|}
\hline Groups & $\mathbf{1}^{\text {st }}$ & $\mathbf{2}^{\text {nd }}$ & $\mathbf{3}^{\text {rd }}$ & $\mathbf{4}^{\text {th }}$ & $\mathbf{5}^{\text {th }}$ & $\mathbf{6}^{\text {th }}$ \\
& Week & Week & Week $^{\text {Week }}$ & Week $^{\text {Week }}$ \\
\hline Control & 1.46 & 1.70 & 1.94 & 1.51 & 2.34 & 3.07 \\
& $\pm 0.12^{\mathrm{b}}$ & \pm 0.06 & \pm 0.01 & $\pm 0.04^{\mathrm{b}}$ & \pm 0.10 & \pm 0.12 \\
\hline Aflatoxin & 1.97 & 1.92 & 2.00 & 1.80 & 2.39 & 3.40 \\
& $\pm 0.11^{\text {a }}$ & \pm 0.06 & \pm 0.19 & $\pm 0.07^{\text {a }}$ & \pm 0.19 & \pm 0.35 \\
\hline Turmeric + & 1.74 & 1.81 & 1.88 & 1.70 & 2.55 & 3.38 \\
Aflatoxin & $\pm 0.09^{\text {a }}$ & \pm 0.07 & \pm 0.05 & $\pm 0.08^{\text {ab }}$ & \pm 0.09 & \pm 0.14 \\
\hline Level of & & & & & & \\
Significance & $* *$ & NS & NS & $*$ & NS & NS \\
\hline
\end{tabular}

Values are mean \pm SE of 30 observations $(n=30)$

Mean with different superscript in column wise are differing significantly

$* * \mathrm{P}<0.01, * \mathrm{P}<0.05$, NS- Non Significant

Table.5 Effects of supplementation of $C$. longa on overall live weight (g) at 6 weeks in induced aflatoxicosis in broiler birds

\begin{tabular}{|l|l|l|l|}
\hline \multicolumn{1}{|c|}{ Groups } & \multicolumn{1}{c|}{ Control } & \multicolumn{1}{c|}{ Aflatoxin } & \multicolumn{1}{c|}{ Aflatoxin + Turmeric } \\
\hline Replicate 1 & 1722.5 & 1368 & 1453 \\
\hline Replicate 2 & 1711.333 & 1404 & 1507 \\
\hline Replicate 3 & 1704.6 & 1371 & 1491 \\
\hline Mean + S.E & $1712.81 \pm 5.22^{\text {a }}$ & $1381 \pm 11.53^{\mathrm{c}}$ & $1483.67 \pm 16.01^{\mathrm{b}}$ \\
\hline
\end{tabular}

Values are mean \pm SE of 30 observations $(n=30)$

Mean with different superscript in row wise are differing significantly $(\mathrm{P}<0.01)$

Table.6 Effects of supplementation of $C$. longa on overall body weight gain (g) at 6 weeks in induced aflatoxicosis in broiler birds

\begin{tabular}{|l|l|l|l|}
\hline \multicolumn{1}{|c|}{ Groups } & \multicolumn{1}{c|}{ Control } & \multicolumn{1}{c|}{ Aflatoxin } & \multicolumn{1}{c|}{ Aflatoxin + Turmeric } \\
\hline Replicate 1 & 1675.9 & 1328.23 & 1408.79 \\
\hline Replicate 2 & 1664.58 & 1354.76 & 1462.08 \\
\hline Replicate 3 & 1656.6 & 1326.87 & 1441.93 \\
\hline Mean + S.E & $1665.69 \pm 5.59^{\text {a }}$ & $1336.62 \pm 9.07^{\mathrm{c}}$ & $1437.60 \pm 15.53^{\mathrm{b}}$ \\
\hline
\end{tabular}

Values are mean \pm SE of 30 observations $(n=30)$

Mean with different superscript in row wise are differing significantly $(\mathrm{P}<0.01)$

Table.7 Effects of supplementation of $C$. longa on overall feed consumption $(\mathrm{g})$ at 6 weeks in induced aflatoxicosis in broiler birds

\begin{tabular}{|l|l|l|l|}
\hline \multicolumn{1}{|c|}{ Groups } & \multicolumn{1}{c|}{ Control } & \multicolumn{1}{c|}{ Aflatoxin } & \multicolumn{1}{c|}{ Aflatoxin + Turmeric } \\
\hline Replicate 1 & 3523 & 3101 & 3270 \\
\hline Replicate 2 & 3426 & 3056 & 3218 \\
\hline Replicate 3 & 3428 & 3024 & 3207 \\
\hline Mean + S.E & $3459 \pm 32.00^{\text {a }}$ & $3060.33 \pm 22.33^{\text {c }}$ & $3231.67 \pm 19.43^{\text {b }}$ \\
\hline
\end{tabular}

Values are mean \pm SE of 30 observations $(n=30)$

Mean with different superscript in row wise are differing significantly $(\mathrm{P}<0.01)$ 
Table.8 Effects of supplementation of $C$. longaon overall feed conversion ratio $(\mathrm{g})$ at 6 weeks in induced aflatoxicosis in broiler birds

\begin{tabular}{|l|l|l|l|}
\hline \multicolumn{1}{|c|}{ Groups } & \multicolumn{1}{|c|}{ Control } & \multicolumn{1}{c|}{ Aflatoxin } & \multicolumn{1}{c|}{$\begin{array}{c}\text { Aflatoxin + } \\
\text { Turmeric }\end{array}$} \\
\hline Replicate 1 & 2.10 & 2.33 & 2.32 \\
\hline Replicate 2 & 2.06 & 2.26 & 2.20 \\
\hline Replicate 3 & 2.07 & 2.28 & 2.22 \\
\hline Mean + S.E & $2.07 \pm 0.01^{\mathrm{b}}$ & $2.29 \pm 0.02^{\mathrm{a}}$ & $2.25 \pm 0.04^{\mathrm{a}}$ \\
\hline
\end{tabular}

Values are mean \pm SE of 30 observations $(n=30)$

Mean with different superscript in row wise are differing significantly $(\mathrm{P}<0.01)$

Table.9 Effects of supplementation of $C$. longa on relative organ weights at $6^{\text {th }}$ week in induced aflatoxicosis in broiler birds

\begin{tabular}{|l|l|l|l|l|l|l|l|}
\hline Groups & Liver & Kidneys & Spleen & Thymus & $\begin{array}{l}\text { Bursa of } \\
\text { Fabricius }\end{array}$ & Heart & Lungs \\
\hline Control & 12.72 & 4.41 & 0.63 & 1.88 & 1.11 & 3.60 & 3.08 \\
& $\pm 0.54^{\mathrm{c}}$ & $\pm 0.26^{\mathrm{c}}$ & $\pm 0.05^{\mathrm{b}}$ & \pm 0.29 & \pm 0.16 & \pm 0.42 & \pm 0.23 \\
\hline Aflatoxin & 21.64 & 6.29 & 1.37 & 1.84 & 0.95 & 3.61 & 3.45 \\
& $\pm 1.62^{\mathrm{a}}$ & $\pm 0.46^{\mathrm{a}}$ & $\pm 0.19^{\mathrm{a}}$ & \pm 0.22 & \pm 0.14 & \pm 0.47 & \pm 0.18 \\
\hline Turmeric & 16.64 & 5.41 & 1.02 & 1.82 & 1.01 & 3.58 & 3.38 \\
+aflatoxin $^{\text {+afla }}$ & $\pm 0.84^{\mathrm{b}}$ & $\pm 0.33^{\mathrm{b}}$ & $\pm 0.07^{\mathrm{a}}$ & \pm 0.16 & \pm 0.23 & \pm 0.16 & \pm 0.26 \\
\hline
\end{tabular}

Values are mean \pm SE of 6 observations $(\mathrm{n}=6)$

Mean with different superscript in column wise are differing significantly $(\mathrm{P}<0.01)$

Fig.1 Effects of supplementation of $C$. longa on weekly live weight $(\mathrm{g})$ in induced aflatoxicosis in broiler birds

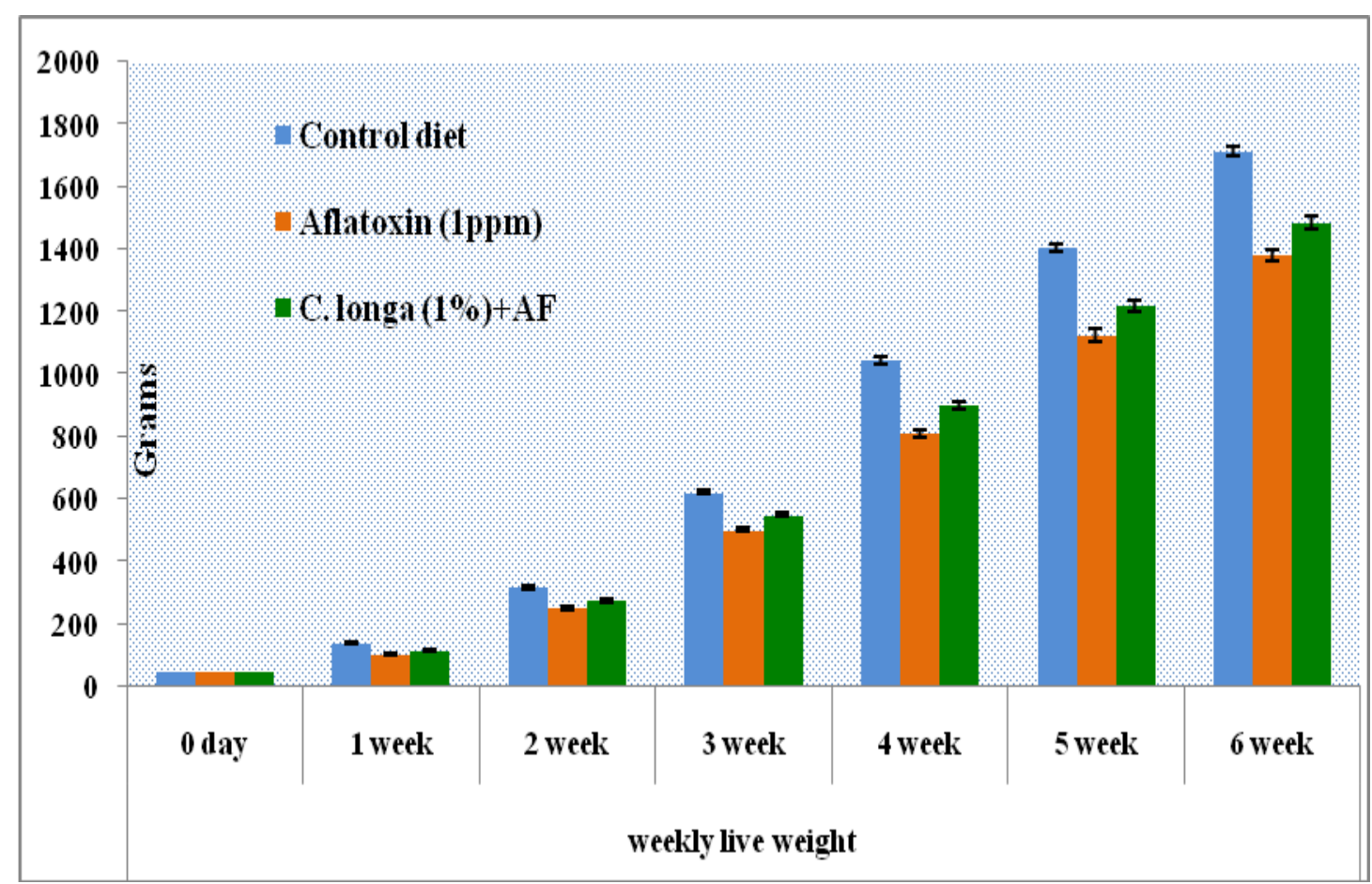


Fig.2 Effects of supplementation of $C$. longa on weekly body weight gain $(\mathrm{g})$ in induced aflatoxicosis in broiler birds

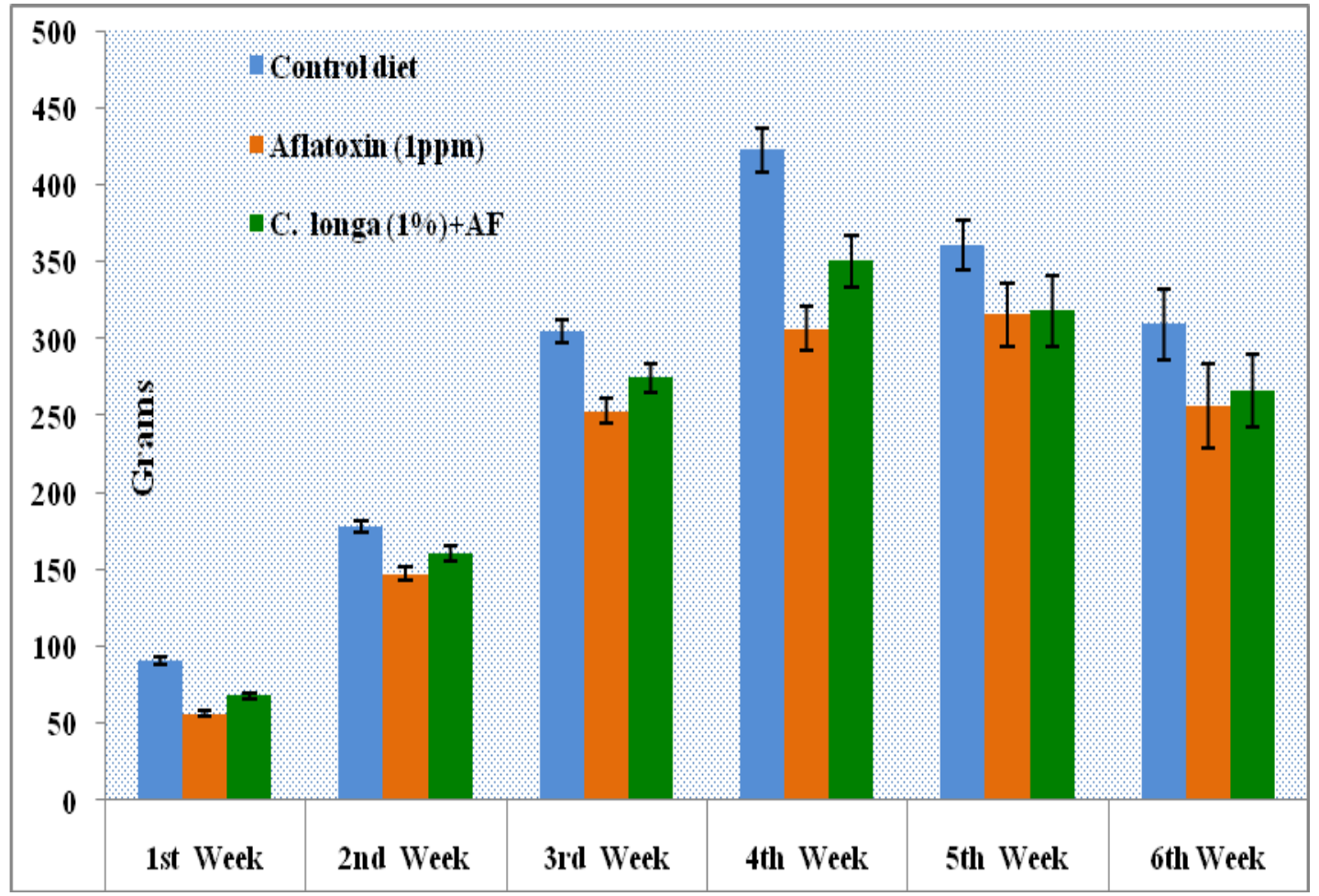

Fig.3 Effects of supplementation of C. longa on weekly feed consumption ( $\mathrm{g}$ ) in induced aflatoxicosisin broiler birds

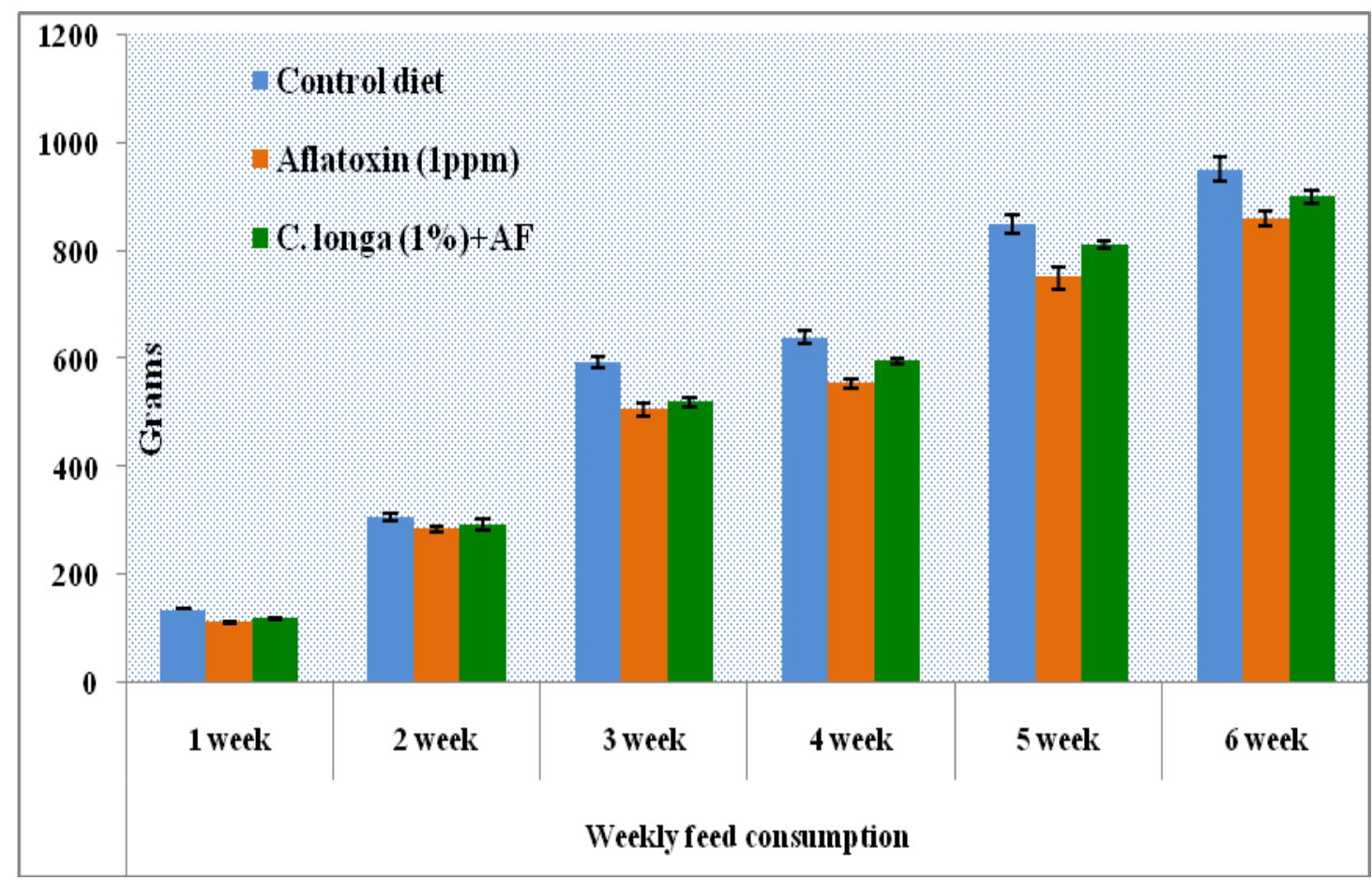


Fig.4 Effects of supplementation of $C$. longa on weekly feed conversion ratio in induced aflatoxicosis in broiler birds

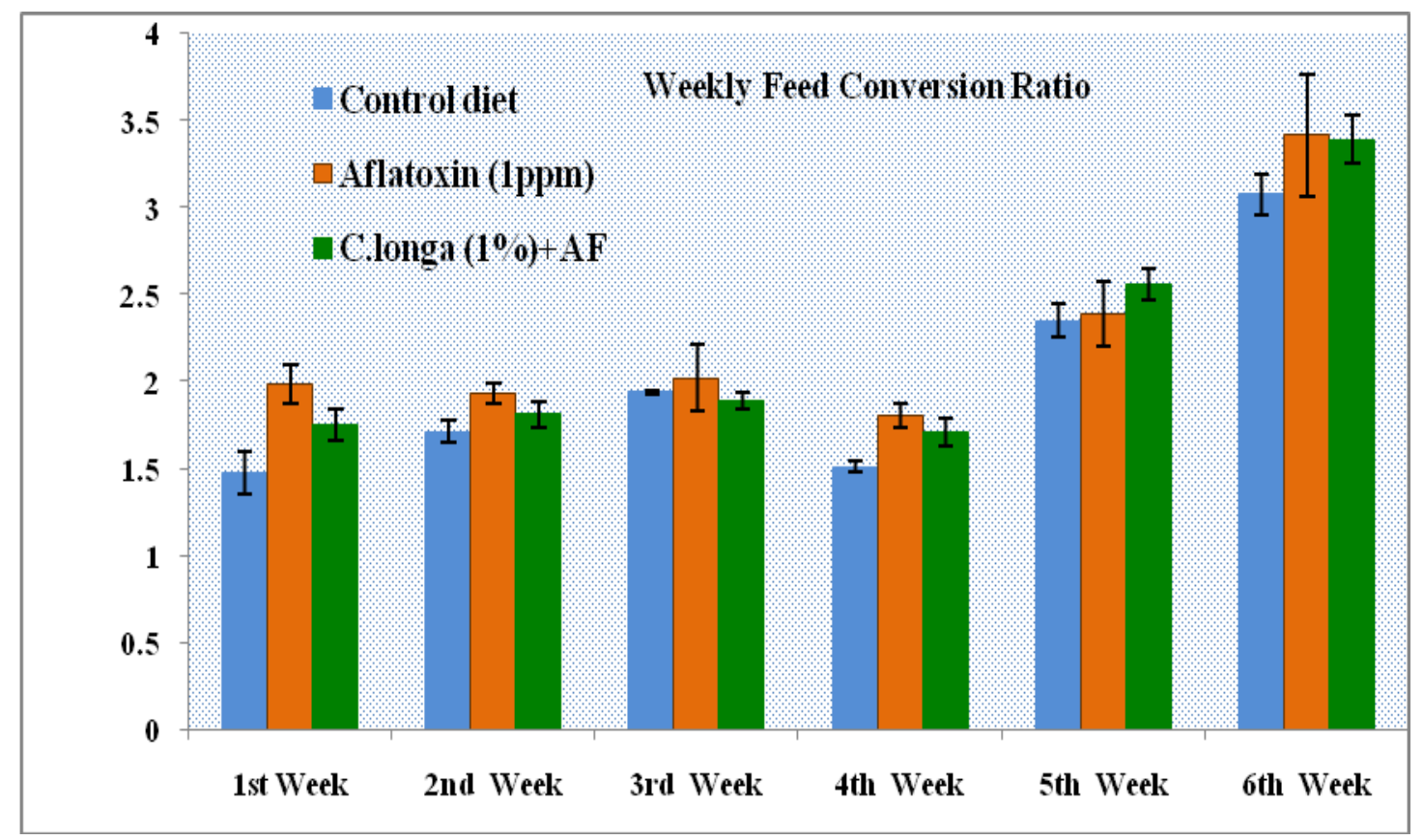

Fig.5 Effects of supplementation of $C$. longa on overall live weight, body weight gain \& feed consumption $(\mathrm{g})$ at 6 weeks in induced aflatoxicosis in broiler birds

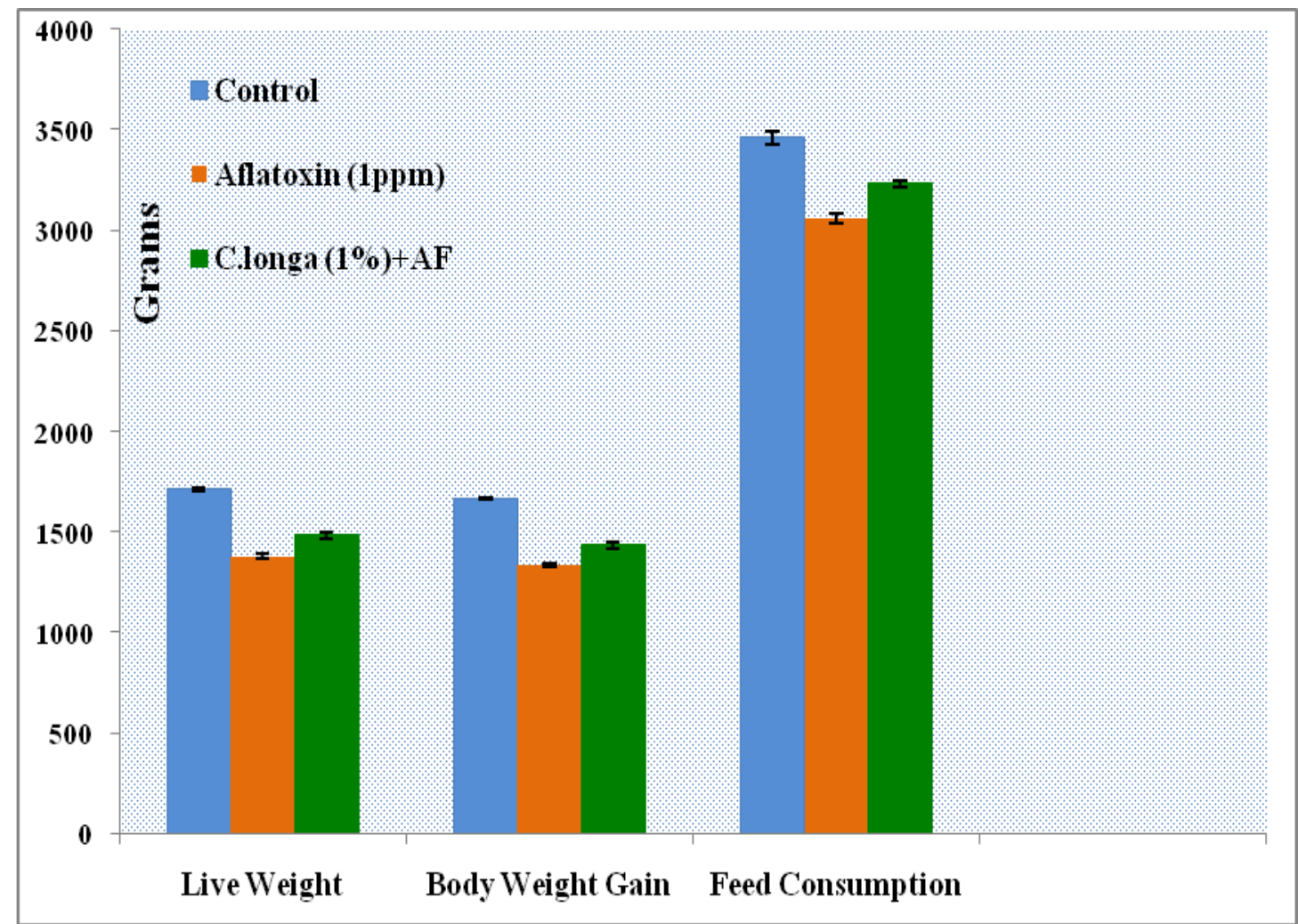


Fig.6 Effects of supplementation of $C$. longa on overall food conversion ratio at 6 weeks in induced aflatoxicosis in broiler birds

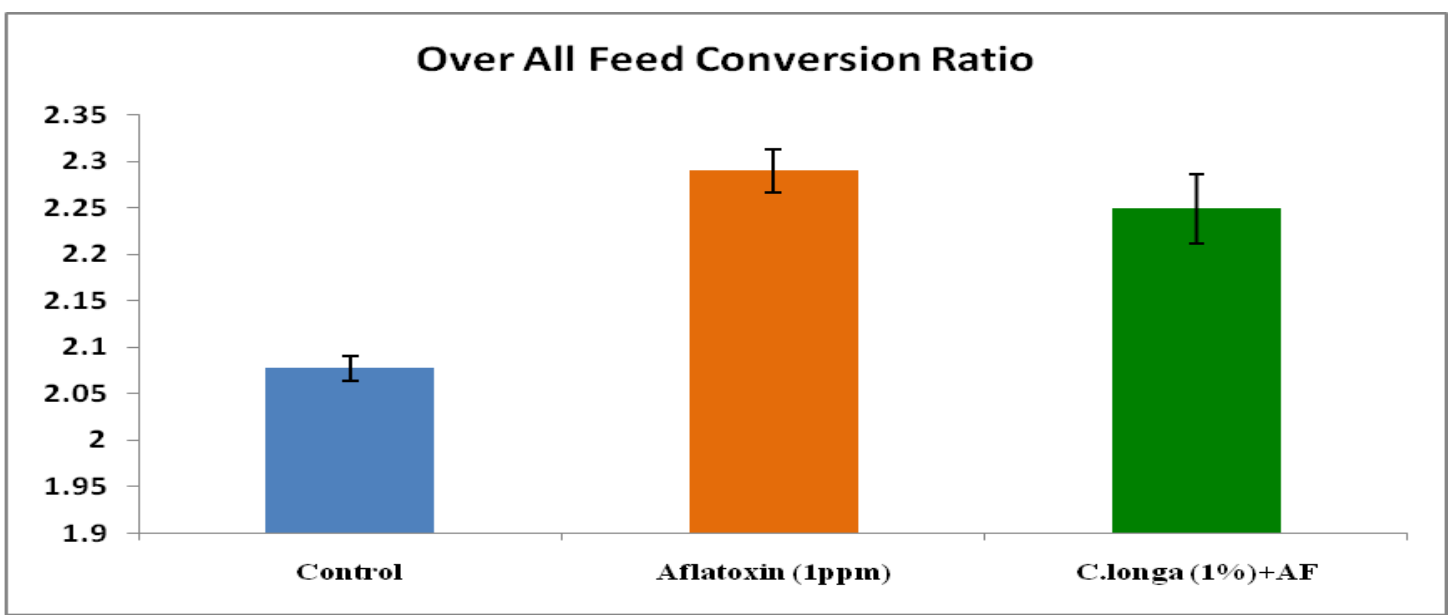

Fig.7 Effects of supplementation of $C$. longa on relative weights of liver and kidneys at $6^{\text {th }}$ week in induced aflatoxicosis in broiler birds
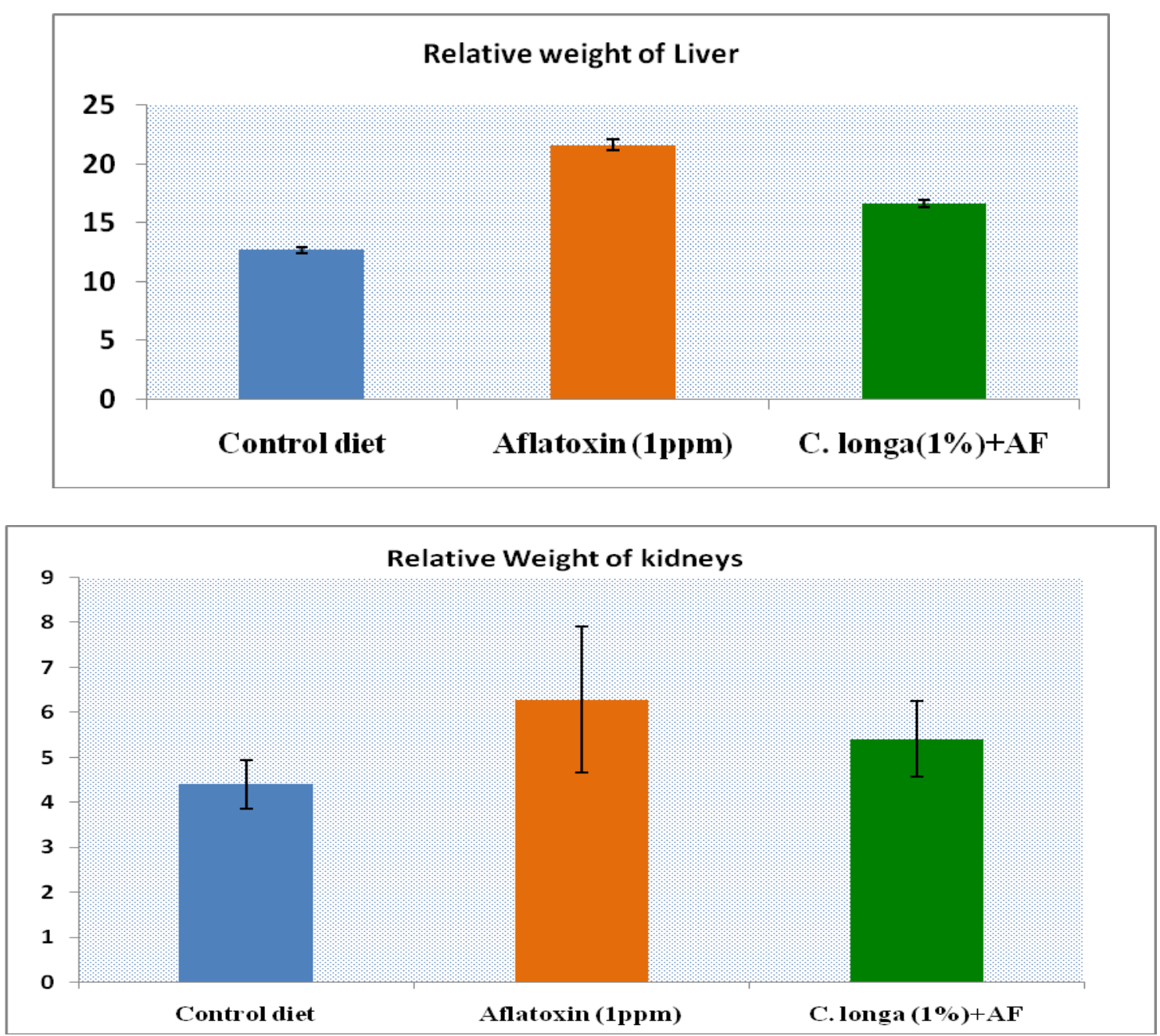


\section{Effect on overall body weight gain}

The overall live weight and body weight gain of the birds of different groups was presented in Tables 5, 6 and Figure 5. The overall body weight gain at 6 week in the control, aflatoxin alone and C. longa $+\mathrm{AF}$ treated groups of birds were $1665.69 \pm 5.59,1336.62 \pm 9.07$ and $1437.60 \pm 15.53$ grams, respectively. The overall body weight gain of both $\mathrm{AF}$ alone and $C$. longa $+\mathrm{AF}$ treated groups at 6 weeks were significantly reduced $(\mathrm{p}<0.01)$ as compared to control. However, the same was significantly increased $(\mathrm{p}<0.01)$ in $C$. longa + $\mathrm{AF}$ treated groups as compared to birds treated with only AF.

Aflatoxin $\mathrm{B}_{1}$ administered at the rate of $1 \mathrm{ppm}$ alone in feed for 42 consecutive days produced a significant reduction in live weight and body weight gain compared to that of the control. These findings are in concurrence with the observation of Dalvi and Mcgowan (1984), Balachandran and Ramakrishnan (1987), Ghosh and Chauhan (1991), Vasan et al., (1998), Gowda et al., (2008), Yarru et al., (2009a) and Manafi and Khosravinia, 2013).

Reduced live weight and body weight gain are expected of a toxic compound like AF, which inhibits functions, as vital as proteins and nucleic acid synthesis and lipogenesisis (Smith and Hamilton, 1970). Yarru et al., (2009 a) also observed similar reduction in the body weight gain and recognized the genes associated with oxidative phosphorylation, ATP synthesis and carnitinepalmitoyl transferase, which transports long chain fatty acids into mitochondria for energy release, were down regulated in birds fed with $\mathrm{AF}(1 \& 2 \mathrm{ppm})$ which leads to decreased energy production. The insulin like growth factor gene was also down regulated in birds fed with AF. This could lead to decreased growth rate of birds, which is in turn reflected by their reduced body weight gain.

In the present study, inclusion of $C$. longa (1\%) to the AF proved to be moderately effective in improving live weight and body weight gain. These results endorse the findings of Kurkure et al., (2001), Gowda et al., (2008) and Yarru et al., (2009 a). The improvement in the live weight and the weight gain could be attributed to curcumin, the major antioxidant ingredient of $C$. longa, is known to inhibit the biotransformation of $\mathrm{AFB}_{1}$ to aflatoxicol in liver (Lee et al., 2001) and thereby reducing the toxicity and stimulating the protein synthesis (Durrani et al., 2006).

\section{Effect on overall feed consumption}

The Overall feed consumption of the birds of different groups was presented in Table 7 and Figure 5. The Overall feed consumption at 6 weeks in the control, aflatoxin alone and $C$. long $a+\mathrm{AF}$ treated groups of birds were 3459 $\pm 32.00,3060.33 \pm 22.33,3231.67 \pm 19.43$ grams, respectively. The Overall feed consumption of $\mathrm{AF}$ alone and $C$. longa $+\mathrm{AF}$ treated groups at 6 weeks was significantly reduced $(\mathrm{p}<0.01)$ as compared to control. However, the same was significantly increased $(\mathrm{p}<0.01)$ in $C$. longa $+\mathrm{AF}$ treated groups as compared to birds treated with only AF.

\section{Effect on overall feed conversion ratio}

The Overall feed conversion ratio of the birds of different groups was presented in Table 8 and Figure 6. The overall feed conversion ratio at 6 weeks in the control, aflatoxin alone and $C$. longa $+\mathrm{AF}$ treated groups of birds were $2.07 \pm 0.01,2.29 \pm 0.02,2.25 \pm 0.04$, respectively. The Overall feed conversion ratio of $\mathrm{AF}$ alone and $C$. longa $+\mathrm{AF}$ treated groups at 6 weeks were significantly increased $(p<0.01)$ as compared to control, but no significant difference was observed in this respect between birds treated with $C$. 
longa $+\mathrm{AF}$ and birds treated with only AF. In the current study, there was a significant reduction in overall feed consumption, and increased FCR in AF alone treated birds. Corroborative observations were reported by Ghosh and Chauhan (1991), Mani and Sundaresan (1998) and Vasan et al., (1998). The poor feed conversion efficiency in AF alone fed group is mainly due to the impaired nutrient absorption (Tung and Hamilton, 1973). Supplementation of $C$. longa improved the feed consumption when compared with the $\mathrm{AF}$ alone treated groups, which can be attributed to the hepato protective properties of $C$. longa which stems from its potent antioxidant effects, anti-inflammatory and cholerectic activity (Luper, 1999) which reduce the hepatotoxic effects associated with the AF. However, the FCR is not improved between the birds treated with $\mathrm{AF}$ alone and C. longa $(1 \%)+\mathrm{AF}$.

The effect of supplementation of Curcuma longa on relative organ weights in induced aflatoxicosis in broiler birds

The effects of supplementation of C. longa on various relative organ weights like liver, kidneys, spleen, thymus, bursa of Fabricius, heart and lungs in induced aflatoxicosis in broiler birds were presented in Table 9 and Figure 7.

The relative weights of liver and kidneys (Mean \pm S.E) observed at $6^{\text {th }}$ week in the control, aflatoxin alone $(1 \mathrm{ppm})$ and $C$. longa $(1 \%)+\mathrm{AF}(1 \mathrm{ppm})$ treated groups of birds were $12.72 \pm 0.54,21.64 \pm 1.62,16.64 \pm 0.84$ and $4.41 \pm 0.26,6.29 \pm 0.46,5.41 \pm$ 0.33 ,respectively.

From the above results, it was observed supplementation of $1 \mathrm{ppm}$ aflatoxin alone and supplementation of $C$. longa $(1 \%)+$ the $\mathrm{AF}(1$ $\mathrm{ppm})$ in feed caused a significant increase $(p<0.01)$ in the relative weights of both liver and kidneys at $6^{\text {th }}$ week as compared to control but the relative weights of both liver and kidneys of the birds in C. longa $+\mathrm{AF}$ treated group were significantly lower $(\mathrm{p}<0.01)$ than the AF alone treated group.

The relative weights of spleen, thymus and bursa of Fabricius (Mean \pm S.E) observed at $6^{\text {th }}$ week in control, aflatoxin alone $(1 \mathrm{ppm})$ and C. longa $(1 \%)+\mathrm{AF}(1 \mathrm{ppm})$ treated groups of birds were $0.63 \pm 0.05,1.37 \pm 0.19$, $1.02 \pm 0.07$ and $1.88 \pm 0.29,1.84 \pm 0.22,1.82$ \pm 0.16 and $1.11 \pm 0.16,0.95 \pm 0.14,1.01 \pm$ 0.23 , respectively.

The results indicated that the supplementation of $1 \mathrm{ppm}$ aflatoxin alone and supplementation of C. longa (1\%) + the AF (1 ppm) in feed caused a significant increase $(p<0.01)$ in the relative weight of spleen at $6^{\text {th }}$ week as compared to control. As regards to the thymus and bursa of Fabricius, there was no significant difference in the relative weights among the different treatments.

The relative weights of heart and lungs (Mean \pm S.E) observed at $6^{\text {th }}$ week in the control, aflatoxin alone (1 ppm) and C. longa $(1 \%)+$ $\mathrm{AF}(1 \mathrm{ppm})$ treated groups of birds were 3.60 $\pm 0.42,3.61 \pm 0.47,3.58 \pm 0.16$ and $3.08 \pm$ $0.23,3.45 \pm 0.18,3.38 \pm 0.26$, respectively. The results showed that there was no significant difference in the relative weights of heart and lungs among the different treatments.

Aflatoxin increased the relative weights of liver, kidneys and spleen in the current study. This is in concurrence with the earlier findings of Smith and Hamilton (1970), Huff et al., (1986), Yarru et al., (2009). Earlier investigators have attributed the increase in the relative weight of the liver, induced by aflatoxin, to an accumulation of lipid in the liver, which produces characteristic, enlarged, friable, fatty liver associated with 
aflatoxicosis of broilers. Tung et al., (1975) related the enlargement of spleen to concurrent occurrence of haemolytic anemia caused by Yarrruet al., (2009) reported that the genes involved in fatty acid metabolism (lipoprotein lipase precursor, peroxisomal bifunctional enzyme) were down regulated in birds fed with $\mathrm{AFB}_{1}$, as a result, fatty acids were not metabolized and they accumulated in the liver, which leads to the fatty livers and increased liver weights. Furthermore, down regulation of carnitinepalmitoyl transferase gene could also contribute to fatty liver condition because of impaired long chain fatty acid transport into mitochondria.

The co-administration of $C$. longa (1\%) with the AF reduced the relative weights liver and kidney. The present findings endorses the reports of kurkure et al., (2000) who also reported the decreased in relative liver weights and attributed to the hepatoprotective properties of the $C$. longa.

The present experiment showed that broiler chicks consuming an aflatoxin (1 ppm) supplemented diet experienced a significant decrease in body weight gain with a poorer feed efficiency. The addition of $C$. longa rhizome powder $(1 \%)$ to the aflatoxincontaminated diet could only partially reduced the negative effect of aflatoxin on growth performance of broiler birds.

\section{References}

Abedi, A and Talebi, E. 2015.Effect of aflatoxins on poultry production and controlmethods of destructive influence. Journal of Agricultural and Biological Science. 10(12): 441-446.

Balachandran, C. and Ramakrishnan, R. 1987(a). Influence of dietary aflatoxin on growth rate and haematology in broiler chicken. Indian J. Poult. Sci., 22(2): 105-108.
Blount, W.P. 1961. Turkey "X" disease. J. Brit. Turkeys. Fed., 9: 52-54. In: Toxicology of aflatoxins Health. Veterinary and Agricultural significance. 1994. (Ed) Eaton, L.D and Groopman, D.J. 1994. Academic Press, London. pp 9.

Dalvi, R.R. and Mcgowan, C. 1984. Experimental induction of chronic aflatoxicosis in chickens by purified aflatoxin B1 and its reversal by activated charcoal, phenobarbital, and reduced glutathione. Poult. Sci. 63: 485491.

Durrani, F.R., Ismial, M., Sultan, A., Suhail, S.M., Chand, N. and Durrani, Z. 2006. Effect of different levels of feed added turmeric (Curcuma longa) on the performance of broiler chicks. J Agr. Biol. Sci. 1(2): 9-11.

Firozi, P.F., Boobaker, V.S. and Bhattacharya, R.K. 1996. Action of curcumin on the cytochrome P450system catalyzing the activation of aflatoxin $\mathrm{B}_{1}$. Chem. Biol. Interact. 100: 41-51.

Ghosh, R.C. and Chauhan, H.V.S. 1991. Effect of purified aflatoxin B1 on the performance of broiler chicks. Indian $\mathrm{J}$. Anim. Hlth. 30: 59-62.

Gowda, N.K.S., Ledoux, D.R., Rottinghaus, G.E., Bermudez, A.J. and Chen, Y.C. 2008. Efficacy of Turmeric (Curcuma longa), containing a known level of Curcumin, and a Hydrated Sodium Calcium Aluminosilicate to ameliorate the adverse effects of aflatoxin in Broiler Chicks. Poult. Sci. 87: 11251130.

Huff, W.E., Kubena, L.F., Harvey, R.B., Corrier, D.E. and Mollenhauer, H.H. 1986. Progression of aflatoxicosis in broiler chickens. Poult. Sci. 65: 18911899.

Kurkure, N.V., Pawar, S.P., Kognole, S.M., Bhanderkar, A.G., Gaonorkar, A.G. and 
Kalorey, D.R. 2000. Ameilorative effect of turmeric (Curcuma longa) in induced aflatoxicosis in cockrels. Indian J. Vet. Path. 24: 26-28.

Kurkure, N.V., Pawar, S.P., Kognole, S.M., Gaonorkar, A.G., Bhanderkar, A.G. and Kalorey, D.R. 2001. Prevention of aflatoxin induced toxicity by turmeric in cockreals haematology and biochemical study. Indian J. Vety. Res. 10: 35-40.

Lee, S.E., Campbell, B.C., Russel, J., Molyneux, C., Hasegawa, S. and Lee, H.S. 2001. Inhibitory effects of naturally occurring compounds on aflatoxin $\mathrm{B}_{1}$ biotransformation. J Agric. Food Chem. 49: 5171-5177.

Luper, S. 1999. A Review of plants used in the treatment of Liver disease: Part Two. Alt. Med. Rev. 4(3): 178-188.

Manafi, M and Khosravinia, H. 2013. Effects of Aflatoxin on the Performance of Broiler Breeders and Its Alleviation through Herbal Mycotoxin Binder. J. Agr. Sci. Tech. 15: 55-63

Mani, K. and Sundaresan, K. 1998. Combined effects of aflatoxin B1 and spontaneous IBD exposure of commercial broilers. Cheiron. 27: 59-62.

Osawa, T. 2007. Nephroprotective and hepatoprotective effects of curcuminoids. Adv. Exp. Med. Biol. 595: 407- 423.

Shotwell, D.L., Hesseltine, C.W., Stubblefield, R.D. and Sorenson, G.W. 1966. Production of aflatoxin on rice. Appl. Microbiol., 14: 425-428.

Smith, J.W. and Hamilton, P.B. 1970. Aflatoxicosis in the broiler chicken. Poult. Sci. 49: 207-215.

Tung, H.T. and Hamilton, P.B. 1973. Decreased plasma carotenoids during aflatoxicosis. Poult. Sci. 52 : 80-83.

Vasan, P., Ravi, R. and Purushothaman, M.R. 1998. Effect of feeding graded levels of aflatoxin $\left(\mathrm{AFB}_{1}\right)$ on performance of broiler chicken. Indian J. Poult. Sci. 33(2): 214-216

Yarru, L.P., Settivari, R.S., Antoniou, E., Ledoux, D.R. and Rottinghaus, G.E. 2009. Toxicological and gene expression analysis of the impact of aflatoxin B1 on hepatic function of male broiler chicks. Poult. Sci. 88: 360-371.

Yarru, L.P., Settivari, R.S., Gowda, N.K.S., Antoniou, E., Ledoux, D.R. and Rottinghaus, G.E. 2009 (a). Effects of turmeric (Curcuma longa) on the expression of hepatic genes associated with biotransformation, antioxidant, and immune systems in broiler chicks fed aflatoxin. Poult. Sci. 88: 2620-2627.

\section{How to cite this article:}

Raja, L., Chandan Kumar Singh, M. Mondal, S. Nety and Koley, K.M. 2017. Evaluation of Effect of Curcuma longa Supplementation on Production Parameters and Organ Weights in Induced Aflatoxicosis in Broiler Birds. Int.J.Curr.Microbiol.App.Sci. 6(10): 797-811. doi: https://doi.org/10.20546/ijcmas.2017.610.096 